\title{
羊卓雍错不同湖区水体真菌群落结构及其多样性
}

\author{
郝 兆, 王艳红, 德 吉, 郭小芳* \\ 西藏大学理学院, 拉萨 850000
}

\begin{abstract}
摘要:湖泊水体真菌能够对水体变化做出迅速响应,在湖泊生态系统地球化学循环中扮演着非常重要的角色。以羊卓雍错、空 母错以及沉错为研究对象, 利用高通量测序的方法探讨羊卓雍错水体真菌群落结构及多样性。结果表明, 不同湖区水体理化因 子差异较大。真菌群落主要由子囊菌门(Ascomycota)、被孢霉门(Mortierellomycota)、担子菌门(Basidiomycota) 等组成。 $\alpha$-多样 性指数显示, 羊卓雍错沿岸区 OTU 数显著高于羊卓雍错湖心区, 其他 $\alpha$-多样性指数在不同湖区间差异不显著。NMDS 分析显 示, 各湖区间真菌群落的 $\beta$-多样性差异明显。聚类分析显示, 同一湖区样点间水体真菌群落结构存在不同程度的差异, 空母错 与沉错交接处水体真菌群落结构较为相似。相关性分析及 RDA 分析结果表明, 浊度、化学需氧量、氨氮以及总氮是影响羊卓雍 错水体真菌丰富度的主要理化因子, 总磷和氨氮是影响羊卓雍错各样点水体真菌群落结构的主要理化因子。羊卓雍错水体真 菌资源比较丰富, 人类活动及湖泊水文状况对水体真菌分布有较大影响。
\end{abstract}

关键词: 高原湖泊; 羊卓雍错;水体真菌;多样性;理化因子

\section{Community structure and diversity of the aquatic fungal in different areas of Yamzhog Yumco Lake}

HAO Zhao, WANG Yanhong, DE Ji, GUO Xiaofang*

School of Science, Tibet University, Lhasa 850000 , China

\begin{abstract}
The aquatic fungal community is highly responsive to lake changes and greatly contributes to biogeochemical processes in lake ecosystems. Based on high-throughput sequencing, we analyzed characteristics of aquatic fungal community structure and diversity at different areas from the Yamzhog Yumco Lake, Kongmo CO Lake, and Chen CO Lake. The results showed that the physicochemical properties of the water were different among the different areas. The fungal community was mainly composed of Ascomycota, Mortierellomycota and Basidiomycota. The results of $\alpha$-diversity index analysis showed that the operational taxonomic units (OTU) number was significantly higher $(P<0.05)$ in coastal area of Yamzhog Yumco Lake than that in Yamzhog Yumco Lake center water, others $\alpha$-diversity index were no significant differences between the different areas. Non-metric multidimensional scaling (NMDS) analysis showed that the $\beta$-diversity of the fungal communities were significantly different among the different areas $(P<0.05)$. The results of the agglomerative clustering analysis showed that the aquatic fungal community structure was different between the various sites on each area, aquatic fungal community structure was similar among the interchange between Kongmo Co Lake and Chen Co Lake. Statistical analysis indicated that turbidity ( NTU), chemical oxygen demand ( COD ), ammonia nitrogen $\left(\mathrm{NH}_{4}^{+}-\mathrm{N}\right)$ and total nitrogen ( TN) were significantly positive related to aquatic fungal richness among different sites. The total phosphorus ( TP) and $\mathrm{NH}_{4}^{+}-\mathrm{N}$ were important factors influencing the community structure of aquatic fungal in the Yamzhog Yumco Lake.
\end{abstract}

基金项目:国家自然科学基金项目(31960024);2019 年中央支持地方高校改革发展基金项目(藏财预指 [2019]01 号);西藏大学科研培育基金 项目(ZDCZJH18-06) ; 西藏大学研究生高水平人才培养计划项目(2018-GSP-014)

收稿日期:2020-11-10; 采用日期:2021-08-16

* 通讯作者 Corresponding author.E-mail: gxf005@ hotmail.com 
The aquatic fungal community from Yamzhog Yumco Lake showed high species richness, hydrologic conditions and anthropogenic influenced were important factors for the aquatic fungal community.

Key Words : plateau lake; Yamzhog Yumco Lake; aquatic fungi ; diversity; environmental factors

湖泊是陆地水圈的重要组成部分, 也是地表各圈层彼此相互作用的节点,在调节区域气候变化、维系区域 生态平衡以及促进区域经济发展等方面发挥着重要作用 ${ }^{[1]}$ 。我国幅员辽阔, 湖泊数量多、类型全、分布广, 全 国面积大于 $1.0 \mathrm{~km}^{2}$ 的湖泊 2759 个, 总面积 $91019.6 \mathrm{~km}^{2}$, 被认为是世界上湖泊生态类型最为丰富的国家之 - ${ }^{[1-2]}$ 。微生物群落作为水生态系统的重要组成部分, 是驱动湖泊等水体地球化学循环和生态系统运行的关 键 ${ }^{[3]}$ 。大量研究表明, 微生物群落不仅是生态系统的功能因子, 其群落结构及多样性还会对环境变化做出迅 速响应, 可以作为衡量湖泊生态系统稳定性的重要指标 ${ }^{[47]}$ 。由于水生生态系统中 $99 \%$ 以上的微生物尚未被 培养出, 这就导致绝大多数的微生物还未被人们所认识 ${ }^{[8]}$ 。高通量测序技术因其不依赖微生物的纯培养, 可 以对微生物群落结构做出更加准确的描述 ${ }^{[9]}$ 。目前, 高通量测序技术对微生物群落结构的研究方法已经比 较成熟, 国内外利用高通量测序技术探讨湖库微生物群落结构及多样性的研究陆续开展, 多数研究表明湖泊 微生物群落结构及多样性主要受环境因素影响, 如温度、溶解氧、 $\mathrm{pH}$ 、电导率以及湖泊营养状态等 ${ }^{[10-17]}$ 。但已 有研究大多针对湖泊细菌群落, 对真菌群落研究相对较少。

青藏高原平均海拔在 $4000 \mathrm{~m}$ 以上, 是全球海拔最高、面积最大的陆地生态系统, 素有“世界屋脊”、“亚洲 水塔”之称 ${ }^{[18]}$ 。青藏高原湖泊资源丰富, 面积在 $1.0 \mathrm{~km}^{2}$ 以上的湖泊 1091 个, 合计总面积 $44993.3 \mathrm{~km}^{2}$, 分别 占全国湖泊总数量和总面积的 $39.5 \%$ 和 $49.5 \%$ 。独特的地理单元及气候条件使得高原湖泊孕育着丰富的 微生物资源 ${ }^{[19]}$ 。羊卓雍错流域位于西藏南部, 流域东西向长 $144 \mathrm{~km}$, 南北向宽 $100 \mathrm{~km}$, 流域面积 $6100 \mathrm{~km}^{2}$, 流域内分布着数个自然湖泊, 常年的自然演变以及人类活动使得各湖泊间水体理化因子存在较大差异, 是研 究高原湖泊水体微生物群落结构及多样性的理想场所 ${ }^{[20-21]}$ 。长期以来, 由于地理位置的限制, 对羊卓雍错流 域生物资源的研究大多集中于鸟类及植物方面 ${ }^{[22-26]}$, 对微生物的研究相对较少, 仅见于湖岸放线菌生防潜力 和多样性研究以及部分湖区沉积物中细菌群落结构垂直分布研究 ${ }^{[27-28]}$ 。开展羊卓雍错水体真菌群落结构及 多样性研究能够为羊卓雍错环境保护以及青藏高原微生物多样性研究提供理论依据, 并为羊卓雍错水体真菌 资源的开发和利用奠定基础。

\section{1 材料与方法}

\section{1 研究区域及水样采集}

羊卓雍错位于青藏高原南部, 西藏自治区山南地区浪卡子县境内, 是雅鲁藏布江南岸和喜马拉雅山北麓 最大的封闭性内陆咸水湖, 与纳木错、玛旁雍错并称为西藏三大圣湖 ${ }^{[29]}$ 。羊卓雍错属高原堰塞湖, 湖泊形状 很不规则, 湖岸曲折蜿蜒, 多年的自然演化使得其主湖区附近独立出空母错、沉错以及巴纠错 3 个小湖。目 前, 主湖区西侧经河道与空母错相连, 空母错东侧经河道与沉错相连 ${ }^{[29]}$ 。空母错主要由冰川融水补给, 水位 较高, 羊卓雍错、沉错以及巴纠错主要以降水补给为主, 冰川融水补给相对较少 ${ }^{[21]}$ 。羊卓雍错湖面海拔为 $4440 \mathrm{~m}$, 湖水平均面积为 $643.98 \mathrm{~km}^{2}$, 平均周长为 $709.41 \mathrm{~km}$, 水深一般为 $30-40 \mathrm{~m}$, 最深可达 $59 \mathrm{~m}$, 湖水储量 约为 $160 \times 10^{8} \mathrm{~m}^{3[30-31]}$ 。羊卓雍错地处喜马拉雅山北坡雨影区, 属藏南山地灌丛草原半干旱气候, 流域年均温 $2.9{ }^{\circ} \mathrm{C}$, 年均降水 $363.4 \mathrm{~mm}, 5-9$ 月降水量占全年降水量的 $90 \%$ 以上 ${ }^{[21,32]}$ 。

2019 年 6 月根据羊卓雍错水体分布情况, 结合生境类型和地理位置差异, 于羊卓雍错、空母错以及沉错 选择 10 个样点进行水样采集, 样点概况见表 1 。为了对羊卓雍错水体真菌群落结构及多样性进行更系统地 分析, 根据各样点所属湖区及地理位置 (图 1), 分别将 1-4 号样点划分为羊卓雍错沿岸区、5-6 号样点划分 为空母错沿岸区、7-8 号样点划分为沉错沿岸区、9-10 号样点划分为羊卓雍错湖心区。利用无菌水体采样 
器采集深度约为 $50 \mathrm{~cm}$ 的水样, 水体温度 ( $T$, temperature)、 $\mathrm{pH}$ 、电导率 ( EC, electric conductivity)、溶解性总固 体 (TDS, total dissolved salt) 以及盐度 (Sal,Salinity) 使用多功能参数仪原位测量 3 次。每个样点分多次采集共 计 $5 \mathrm{~L}$ 的水样, 于两个无菌塑料桶中避光保存,一份水样立即送往拉萨景博环境监测科技有限公司进行总氮 ( TN, total nitrogen)、氨氮 $\left(\mathrm{NH}_{4}^{+}-\mathrm{N}\right.$, ammonia nitrogen)、总磷( $\mathrm{TP}$, total phosphorus)、浊度 ( NTU, turbidity) 以及化 学需氧量 (COD, chemical oxygen demand) 的测定,另一份取 $1 \mathrm{~L}$ 经 $0.22 \mu \mathrm{m}$ 无菌水系滤膜过滤收集菌株, 滤膜 $-80{ }^{\circ} \mathrm{C}$ 储存,用于提取 DNA。

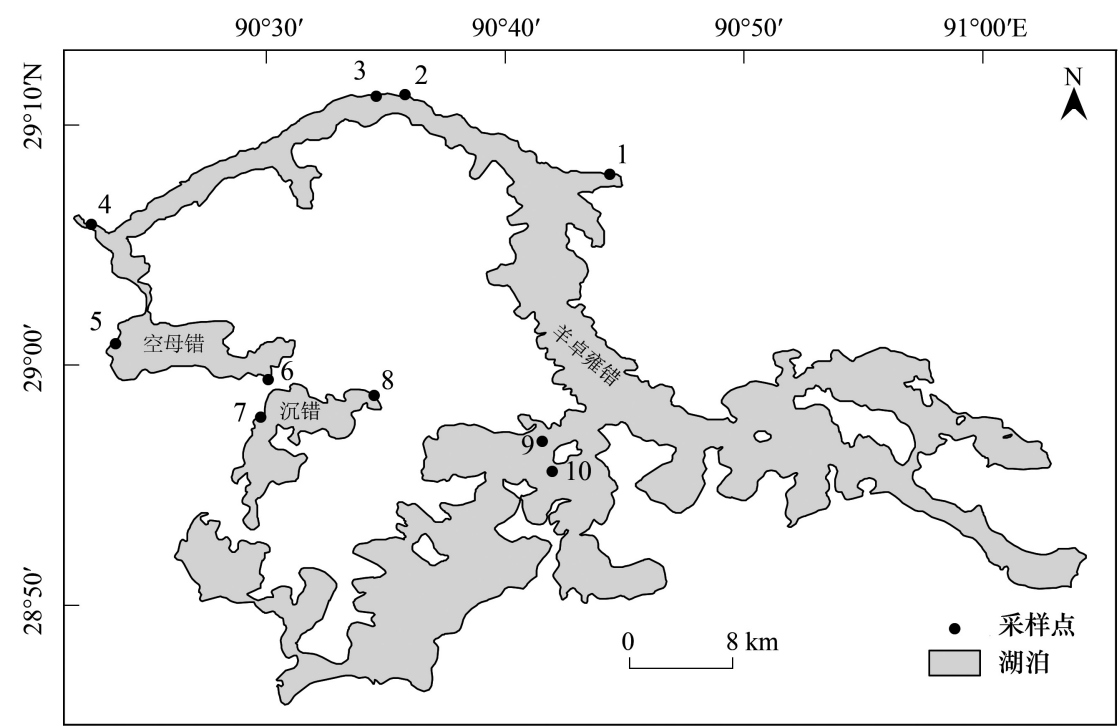

图 1 羊卓雍错流域水体采集样点分布

Fig.1 Distribution of sampling sites in Yamzhog Yumco Lake

表 1 羊卓雍错水体采集样点概况

Table 1 General situation of sampling sites in Yamzhog Yumco Lake

\begin{tabular}{cccll}
\hline $\begin{array}{c}\text { 样点 } \\
\text { Location sites }\end{array}$ & $\begin{array}{c}\text { 海拔 } \\
\text { Altitude/m }\end{array}$ & $\begin{array}{c}\text { 经度 } \\
\text { Longitude }\end{array}$ & $\begin{array}{c}\text { 纬度 } \\
\text { Latitude }\end{array}$ & $\begin{array}{l}\text { 生境 } \\
\text { Habitat }\end{array}$ \\
\hline 1 & 4443 & $90^{\circ} 44^{\prime} \mathrm{E}$ & $29^{\circ} 07^{\prime} \mathrm{N}$ & 秀琼村旁表层水 \\
2 & 4442 & $90^{\circ} 35^{\prime} \mathrm{E}$ & $29^{\circ} 11^{\prime} \mathrm{N}$ & 羊卓雍错蓄能电站旁表层水 \\
3 & 4443 & $90^{\circ} 34^{\prime} \mathrm{E}$ & $29^{\circ} 11^{\prime} \mathrm{N}$ & 羊卓雍错观景台旁表层水 \\
4 & 4439 & $90^{\circ} 22^{\prime} \mathrm{E}$ & $29^{\circ} 05^{\prime} \mathrm{N}$ & 羊卓雍错西端畜牧草地旁表层水 \\
5 & 4441 & $90^{\circ} 23^{\prime} \mathrm{E}$ & $29^{\circ} 00^{\prime} \mathrm{N}$ & 空母错西侧哈西旅游接待中心旁表层水 \\
6 & 4447 & $90^{\circ} 30^{\prime} \mathrm{E}$ & $28^{\circ} 59^{\prime} \mathrm{N}$ & 空母错东侧表层水 \\
7 & 4431 & $90^{\circ} 29^{\prime} \mathrm{E}$ & $28^{\circ} 57^{\prime} \mathrm{N}$ & 沉错西侧表层水 \\
8 & 4432 & $90^{\circ} 34^{\prime} \mathrm{E}$ & $28^{\circ} 58^{\prime} \mathrm{N}$ & 沉错东侧表层水 \\
9 & 4438 & $90^{\circ} 41^{\prime} \mathrm{E}$ & $28^{\circ} 56^{\prime} \mathrm{N}$ & 羊卓雍错南部湖心水 \\
10 & 4442 & $90^{\circ} 42^{\prime} \mathrm{E}$ & $28^{\circ} 55^{\prime} \mathrm{N}$ & 羊卓雍错雍布杂寺旁湖心水 \\
\hline
\end{tabular}

\section{2 理化性质测定}

$\mathrm{T} 、 \mathrm{pH} 、 \mathrm{EC} 、 \mathrm{TDS}$ 以及盐度使用多功能参数仪 (Multi-Parameter PCSTestr TM35) 测定。 $\mathrm{TN} 、 \mathrm{NH}_{4}^{+}-\mathrm{N}$ 等 5 个理 化指标由拉萨景博环境监测科技有限公司进行测定,其中 $\mathrm{TN} 、 \mathrm{TP} 、 \mathrm{NH}_{4}^{+}-\mathrm{N}$ 使用 UV5800 紫外可见分光光度计 进行测量, 方法分别为碱性过硫酸钾消解紫外分光光度法、钼酸铵分光光度法和纳氏试剂分光光度法; COD 的测定采用重铬酸盐法进行,浊度的测定采用目视比色法-福尔马肼标准进行。

\subsection{DNA 的提取和高通量测序}

将冷冻保存的样品送往北京诺禾致源科技股份有限公司。DNA 的提取采用 CTAB 法 ${ }^{[33]}$, 利用 $1 \%$ 琼脂糖 
凝胶电泳检测 DNA 的纯度和浓度。采用带 Barcode 的真菌 ITS1 区引物：ITS2- 2043R ( 5'GCTGCGTTCTTCATCGATGC-3') 、ITS5-1737F ( 5'-GGAAGTAAAAGTCGTAACAAGG-3') 以及高效高保真酶进行 PCR。PCR 扩增产物使用 $2 \%$ 琼脂糖凝胶电泳检测, 根据 PCR 产物浓度进行等量混样,充分混匀后使用 $2 \%$ 琼 脂糖凝胶电泳检测, 目标条带使用 Qiagen 公司的胶回收试剂盒回收产物。使用 TruSeq ${ }^{\mathrm{TM}}$ DNA PCR-Free Sample Preparation Kit 进行文库构建, 构建好的文库经过 Qubit 和 Q-PCR 定量, 文库合格后使用 NovaSeq 6000 进行上机测序。

\section{4 数据分析}

根据 Barcode 序列和引物序列从高通量数据中拆分出各样本数据, 截去 Barcode 和引物序列后使用 FLASH V1.2.7 软件对序列进行拼接。拼接得到的原始 Tags 数据 (Raw Tags) 使用 Qiime V1.9.1 软件进行过 滤。使用 Uparse V7.0.1001 软件对过滤后的数据进行聚类, 以 $97 \%$ 的一致性将序列聚类成为可操作分类单元 ( OTU, operational taxonomic units), 使用 Qiime V1.9.1 软件中的 Blast 方法结合 Unit V7.2 数据库进行物种注释 分析, 最后以样本中最小数据量为标准进行均一化处理。

基于均一化处理后的 OTU 数据,使用 Qiime V1.9.1 软件进行 $\alpha$-多样性的计算。相关性分析以及差异性 分析采用 SPSS 20.0 软件的 Pearson 相关性系数法和单因素方差分析 (ANOVA), 多重比较分析使用 Duncan 检验法,完全连接聚合聚类、非度量多维尺度分析以及 ANOSIM 检验使用 R 4.0.1 软件进行, 圥余分析使用 CANOCO 5 软件进行,绘图使用 R 4.0.1 软件以及 Origin 2019 软件进行。

\section{2 结果与分析}

\section{1 羊卓雍错水体理化性质}

羊卓雍错各样点水体理化因子显示 (图 2), 就水体温度而言, 8 号样点水体温度最高, 为 $25.2{ }^{\circ} \mathrm{C}, 9$ 号样 点水体温度最低, 为 $10.7{ }^{\circ} \mathrm{C} ; 10$ 个样点水体 $\mathrm{pH}$ 介于 8.37-9.08 之间, 3 号样点水体 $\mathrm{pH}$ 值最高, 8 号样点则相 对较低。就水体浊度而言, 5 号样点最高, 为 15,6 号及 9 号样点则相对较低, 为 3 ; EC、TDS 以及盐度具有相似 的变化趋势, 各样点 EC 在 523.67-2346.67 $\mu \mathrm{S} / \mathrm{cm}$ 之间、TDS 在 371.67-1666.67 mg/L 之间、盐度在 $0.25-$ $1.18 \mathrm{~g} / \mathrm{L}$ 之间, 其中 3 号及 10 号样点 EC 值相对较高, 1 号、3 号以及 10 号样点 TDS 值相对较高, 1 号、3 号、9 号以及 10 号样点盐度值相对较高, 5 号及 6 号样点 EC、TDS 以及盐度值均相对较低; 就 COD 而言, 9 号样点 相对较低, 其值为 $6.72 \mathrm{mg} / \mathrm{L}, 5$ 号样点相对较高, 其值为 $185.81 \mathrm{mg} / \mathrm{L} ; 10$ 个样点中, 9 号样点 $\mathrm{NH}_{4}^{+}-\mathrm{N}$ 和 $\mathrm{TN}$ 含 量均最低, 分别为 $0.01 \mathrm{mg} / \mathrm{L}$ 和 $0.25 \mathrm{mg} / \mathrm{L}, \mathrm{NH}_{4}^{+}-\mathrm{N}$ 含量最高的是 7 号样点, 为 $0.05 \mathrm{mg} / \mathrm{L}$, TN 含量最高的是 5 号样点, 为 $0.61 \mathrm{mg} / \mathrm{L}$; 就 TP 而言, 5 号及 7 号样点含量较高, 为 $0.06 \mathrm{mg} / \mathrm{L}, 1$ 号样点含量相对较低, 为 0.02 $\mathrm{mg} / \mathrm{L}$ 。

各区域理化因子差异性分析显示 (图 3), 就水体 $\mathrm{pH}$ 值而言, 羊卓雍错沿岸区和羊卓雍错湖心区显著高 于空母错沿岸区和沉错沿岸区; 就 EC、TDS 以及盐度而言, 羊卓雍错沿岸区及羊卓雍错湖心区均显著高于沉 错沿岸区, 沉错沿岸区均显著高于空母错沿岸区; 就 TP 而言, 空母错沿岸区及沉错沿岸区显著高于羊卓雍错 沿岸区; 其他理化因子在各区域间则没有显著差异 $(P>0.05)$ 。

\section{2 羊卓雍错水体浮游真菌多样性特征}

由表 2 可知, 从羊卓雍错各样点水体中共检测到 4649 个 OTU, 其中 4 号样点 OTU 数量较多, 而 9 号样点较 少。各样本 Coverage 指数均在 $99 \%$ 以上, Coverage 指数与各样点稀疏曲线 (图 4)均表明, 本次研究的测序深度已 达到较高水平, 能够代表样本中微生物的真实情况。分析丰富度指数和多样性指数可以发现, Ace 指数与 Chao 1 指数拥有相似的变化趋势, 均表明 7 号、5 号、4 号样点水体真菌丰富度较高而 9 号样点较低。Shannon 指数显 示, 4 号与 7 号样点水体真菌多样性最高, 9 号样点多样性则最低。Simpson 指数表明水体真菌多样性最高的为 7 号和 4 号样点, 水体真菌多样性最低的为 8 号样点。各区域差异性分析显示, 羊卓雍错沿岸区 (CY)OTU 数量显 著高于羊卓雍错湖心区 $(\mathrm{YC})(P<0.05)$, 其他指数在不同区域间的差异则不显著 $(P>0.05)$ 。 

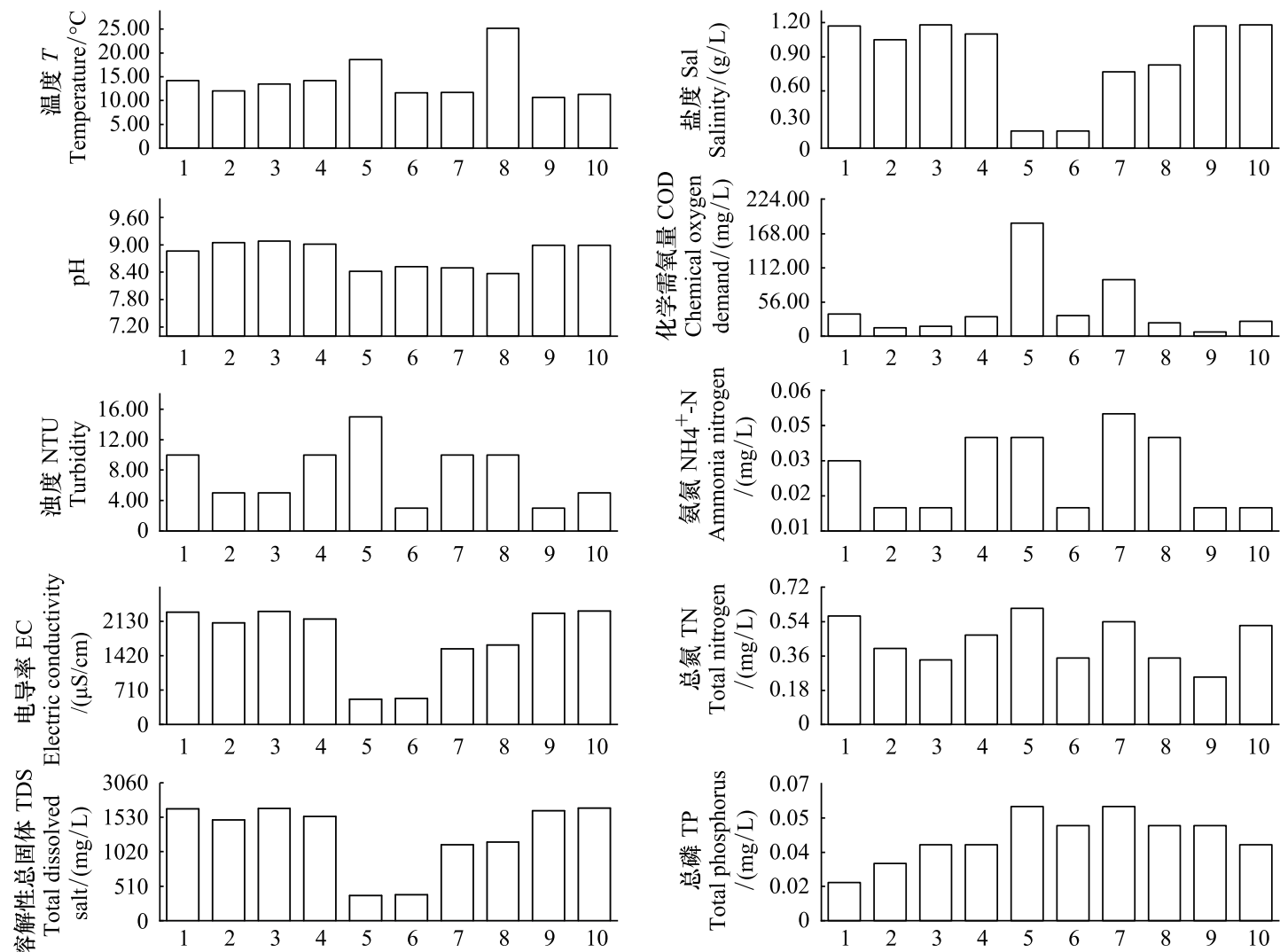

样点 Sites

图 2 羊卓雍错各样点水体理化因子

Fig.2 Aquatic environmental factors of different sites in Yamzhog Yumco Lake

表 2 羊卓雍错水体真菌 $\boldsymbol{\alpha}$-多样性指数

Table 2 The $\alpha$-diversity indexes of aquatic fungal in Yamzhog Yumco Lake

\begin{tabular}{|c|c|c|c|c|c|c|}
\hline \multirow[b]{2}{*}{$\begin{array}{l}\text { 样点 } \\
\text { Sites }\end{array}$} & \multirow{2}{*}{$\begin{array}{l}\text { OTU 数量 } \\
\text { OTUs }\end{array}$} & \multirow{2}{*}{$\begin{array}{c}\text { Coverage 指数 } / \% \\
\text { Coverage }\end{array}$} & \multicolumn{4}{|c|}{ 丰富度及多样性指数 Richness and diversity index } \\
\hline & & & $\begin{array}{c}\text { Ace 指数 } \\
\text { Ace }\end{array}$ & $\begin{array}{c}\text { Chao } 1 \text { 指数 } \\
\text { Chao } 1\end{array}$ & $\begin{array}{c}\text { Shannon 多样性指数 } \\
\text { Shannon }\end{array}$ & $\begin{array}{c}\text { Simpson 多样性指数 } \\
\text { Simpson }\end{array}$ \\
\hline 1 & 541 & 99.6 & 833.52 & 824.44 & 5.30 & 0.89 \\
\hline 2 & 600 & 99.6 & 888.00 & 861.60 & 5.19 & 0.92 \\
\hline 3 & 519 & 99.7 & 706.20 & 702.30 & 5.24 & 0.92 \\
\hline 4 & 710 & 99.4 & 1225.39 & 1169.94 & 6.57 & 0.96 \\
\hline CY 平均 Mean & $593 \mathrm{a}$ & $99.6 \mathrm{a}$ & $913.28 \mathrm{a}$ & $889.57 \mathrm{a}$ & $5.58 \mathrm{a}$ & $0.92 \mathrm{a}$ \\
\hline 5 & 526 & 99.1 & 1251.66 & 1224.23 & 5.25 & 0.92 \\
\hline 6 & 364 & 99.6 & 858.05 & 809.63 & 5.12 & 0.87 \\
\hline CK 平均 Mean & $445 \mathrm{ab}$ & $99.4 \mathrm{a}$ & $1054.86 \mathrm{a}$ & $1016.93 \mathrm{a}$ & $5.19 \mathrm{a}$ & $0.90 \mathrm{a}$ \\
\hline 7 & 558 & 99.1 & 1289.80 & 1266.67 & 6.35 & 0.97 \\
\hline 8 & 478 & 99.6 & 756.98 & 771.86 & 3.73 & 0.70 \\
\hline CC 平均 Mean & $518 \mathrm{ab}$ & $99.4 \mathrm{a}$ & $1023.39 \mathrm{a}$ & $1019.27 \mathrm{a}$ & $5.04 \mathrm{a}$ & $0.84 \mathrm{a}$ \\
\hline 9 & 262 & 99.9 & 323.09 & 304.66 & 3.21 & 0.80 \\
\hline 10 & 415 & 99.6 & 655.69 & 641.57 & 3.74 & 0.80 \\
\hline YC 平均 Mean & $339 b$ & $99.8 \mathrm{a}$ & $489.39 a$ & $473.12 \mathrm{a}$ & $3.48 \mathrm{a}$ & $0.80 \mathrm{a}$ \\
\hline
\end{tabular}

CY: 羊卓雍错沿岸区 Coastal area of Yamzhog Yumco Lake; CK: 空母错沿岸区 Coastal area of Kongmo Co Lake; CC: 沉错沿岸区 Coastal area of Chen Co Lake; YC: 羊卓雍错湖心区 Yamzhog Yumco Lake center; 不同字母代表不同区域间在 $P<0.05$ 水平上差异显著

\section{3 羊卓雍错水体真菌群落结构组成}

对各 OTU 代表序列进行物种注释, 对门水平及属水平下的物种进行分析发现, 由于当前数据库的局限 

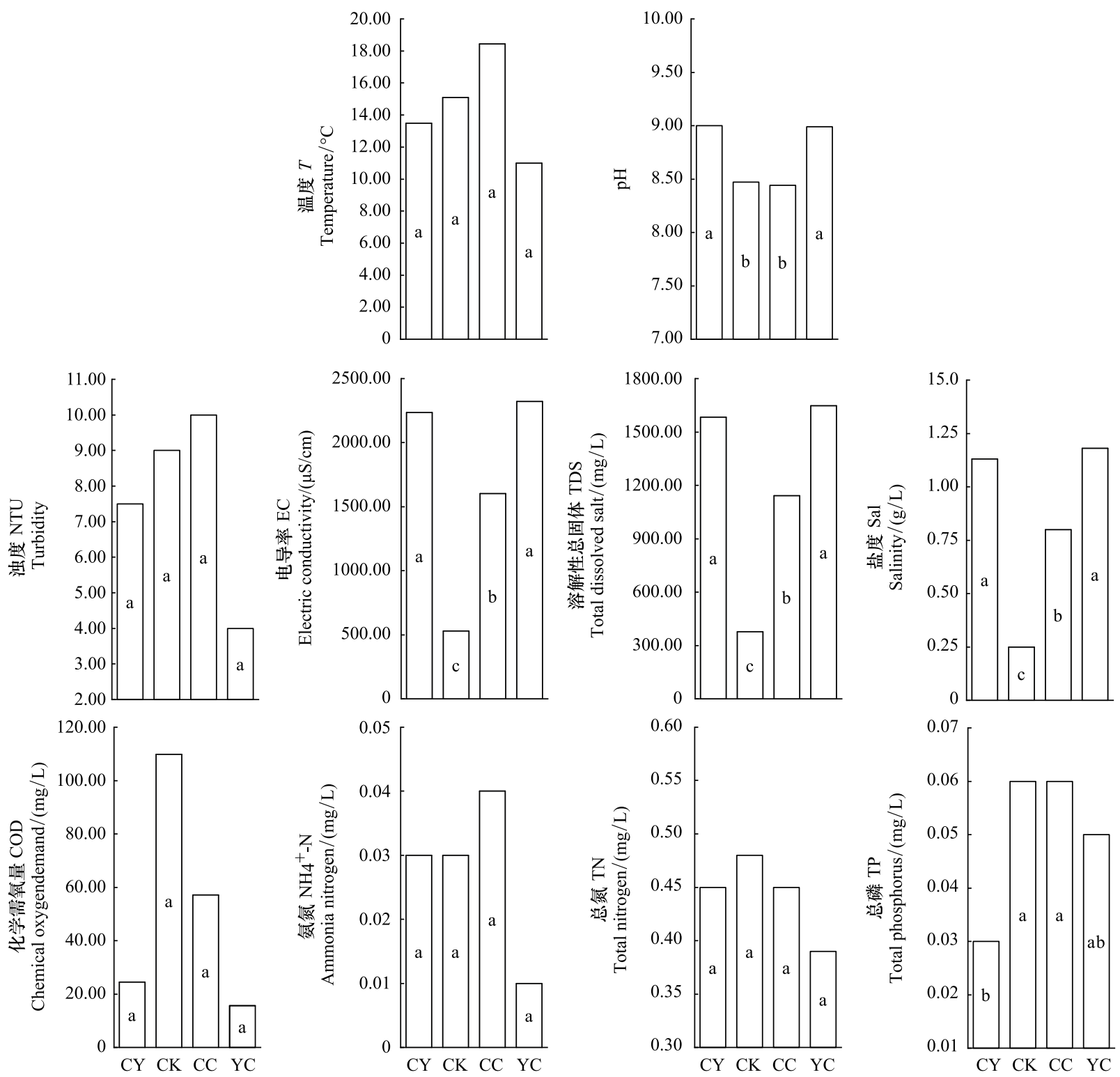

图 3 羊卓雍错各区域水体理化因子差异性分析

Fig.3 Aquatic environmental factors of different regions in Yamzhog Yumco Lake

CY : 羊卓雍错沿岸区 Coastal area of Yamzhog Yumco Lake; CK : 空母错沿岸区 Coastal area of Kongmo Co Lake; CC: 沉错沿岸区 Coastal area of Chen Co Lake; YC: 羊卓雍错湖心区 Yamzhog Yumco Lake center; 不同字母代表不同区域间在 $P<0.05$ 水平上差异显著

性, 本实验中真菌群落较多 OTU 属未知类群, 相似结果在其他研究中也有出现 ${ }^{[11,16,34]}$ 。1-10 号样点门水平 下未知类群所占的比例分别为 $32.1 \% 、 77.3 \% 、 51.5 \% 、 46.6 \% 、 86.5 \% 、 81.2 \% 、 45.1 \% 、 30.3 \% 、 94.4 \% 、 97.3 \%$, 属 水平下未知类群所占的比例分别为 $52.2 \% 、 83.7 \% 、 79.7 \% 、 78.1 \% 、 96.4 \% 、 98.0 \% 、 66.8 \% 、 41.4 \% 、 97.1 \%$ 、 $98.6 \%$ 。为更直观体现各样本相对丰度较高的门类与属类及其比例, 选取门水平下除未知类群外的物种以及 属水平下除未知类群外相对丰度排名前 10 的物种的相对丰度生成柱状堆积图, 结果如图 5 所示。

羊卓雍错各样点水体已注释真菌分属于子囊菌门(Ascomycota)、被孢霉门( Mortierellomycota)、担子菌门 (Basidiomycota)、壶菌门(Chytridiomycota)、毛霉菌门 (Mucoromycota)、罗兹菌门 (Rozellomycota)、球囊菌门 (Glomeromycota) 和捕虫霉亚门 (Zoopagomycota)。由图 5 可知羊卓雍错水体已注释真菌相对丰度最高的门类 为子囊菌门 (Ascomycota), 在各样点相对丰度占比分别为 $12.8 \% 、 26.6 \% 、 72.6 \% 、 16.9 \% 、 47.2 \% 、 80.1 \%$ 、 


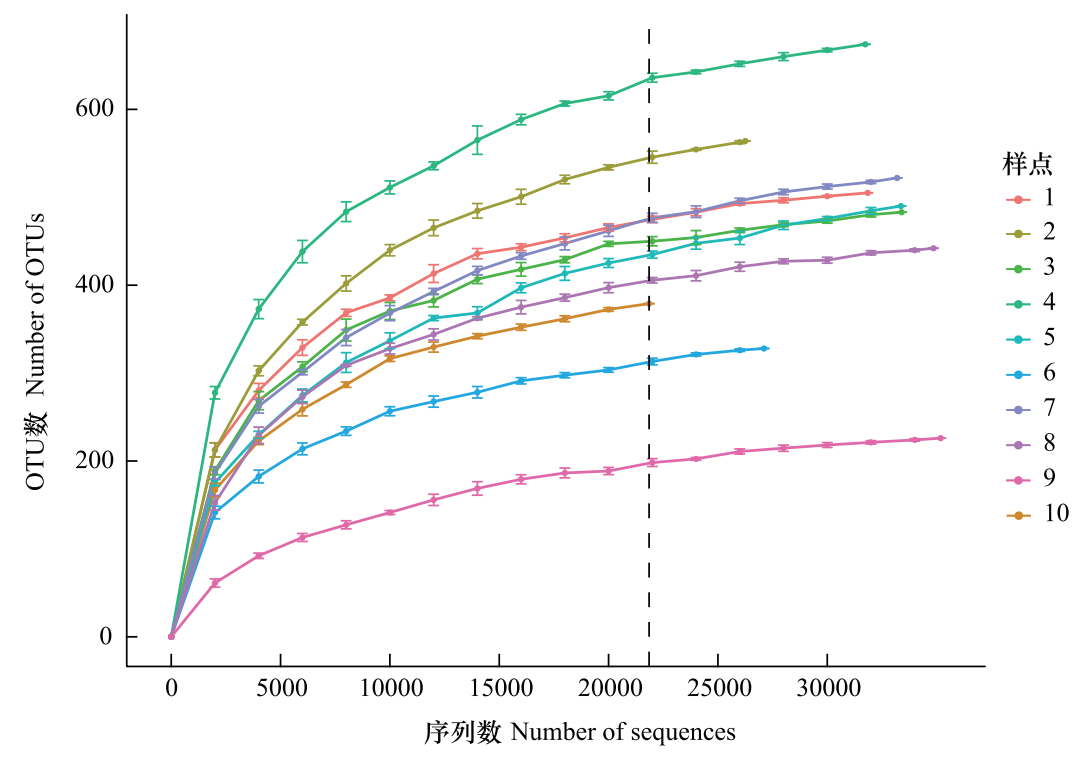

图 4 羊卓雍错水体真菌在 $97 \%$ 水平上的稀疏曲线

Fig.4 Rarefaction curves of aquatic fungal samples in Yamzhog Yumco Lake at cutoff level of $97 \%$ OTU: 可操作分类单元 Operational taxonomic units

$54.4 \% 、 90.3 \% 、 87.1 \% 、 63.0 \%$; 其次为被孢霉门 (Mortierellomycota), 在各样点相对丰度占比分别为 $52.4 \%$ 、 $13.7 \% 、 5.3 \% 、 33.1 \% 、 2.1 \% 、 0.9 \% 、 0.3 \% 、 0.1 \% 、 2.5 \% 、 1.8 \%$; 担子菌门(Basidiomycota) 相对丰度也较高, 在各样 点相对丰度占比分别为 $7.0 \% 、 51.1 \% 、 4.1 \% 、 12.2 \% 、 32.9 \% 、 15.3 \% 、 32.4 \% 、 5.4 \% 、 4.0 \% 、 21.5 \%$ 。由真菌属水平 柱状堆积图可以看出 (图 5), Alternaria 相对丰度最高, 集中表现在 5 号、8 号以及 9 号样点, 其值均在 $78 \%$ 以 上。其次为 Mortierella, 集中表现在 1 号和 4 号样点, 其值分别为 74.5\%和 $80.6 \%$ 。2 号、3 号、6 号、7 号样点中 相对丰度较高的属分别为 Dioszegia、Xalocoa、Russula、Cyberlindnera, 其值分别为 $65.0 \% 、 40.3 \% 、 42.0 \%$ 以及 $55.2 \%$ 。10 号样点真菌属水平分布则较为均匀, Alternaria、Cyberlindnera 以及 Helicoma 均具有较高的相对 丰度。

使用 Venn 图来展示各样点及各区域共有和特有 OTU 数量, 结果如图 6 所示, 虽然各湖区间有水道连接, 但共有 OTU 数量仅为 36 。各区域 Venn 图显示, 羊卓雍错沿岸区 (CY) OTU 数最多, 为 961 ; 其次为沉错沿岸 区 $(C C)$, 为 667 ; 空母错沿岸区 (CK) OTU 数也较多, 为 610 ; 羊卓雍错湖心区 OTU 数则最少, 为 480 。各区域 共有 OTU 数为 197 , 分别占羊卓雍错沿岸区( CY) OTU 数的 $20.5 \%$, 空母错沿岸区( CK) OTU 数的 $32.3 \%$, 沉错 沿岸区 (CC) OTU 数的 $29.5 \%$, 羊卓雍错湖心区 ( YC) OTU 数的 $41.0 \%$ 。各区域间共有 OTU 数显示, 羊卓雍错 沿岸区 (CY) 与沉错沿岸区 (CC) 共有 OTU 比例最高, 占两区域 OTU 数的 $46.0 \%$; 其次为空母错沿岸区 (CK) 与沉错沿岸区 $(C C)$, 占两区域 OTU 数的 $45.4 \%$; 空母错沿岸区 $(C K)$ 与羊卓雍错湖心区 $(\mathrm{YC})$ 共有 OTU 比例 则最低, 为 $32.0 \%$ 。

采用基于 OTU 水平 Bray-Curtis 距离的非度量多维尺度 (NMDS, non-metric multidimensional scaling) 分析 以及采样点完全连接聚合聚类 ( completelinkage agglomerative clustering) 得到不同湖区水体真核微生物群落结 构组成( 图 7)。非度量多维尺度分析结果显示, 不同湖区中的真核微生物群落分别聚为一类, ANOSIM 检验 组间差异显示, 组间差异显著大于组内差异 $(R=0.772, P=0.001)$, 说明分组合理, 4 个湖区真核微生物群落结 构存在一定的差异。相比其他湖区所属样点, 9 号及 10 号样点虽同属羊卓雍错湖心区 ( YC), 但真核微生物 群落结构存在一定差异。完全连接聚合聚类结果显示,位于空母错和沉错连接处两侧的 5 号及 7 号样点真核 微生物群落结构具有较高的相似性, 而距两湖区连接处较远的 6 号及 8 号样点具有较高的相似性。 

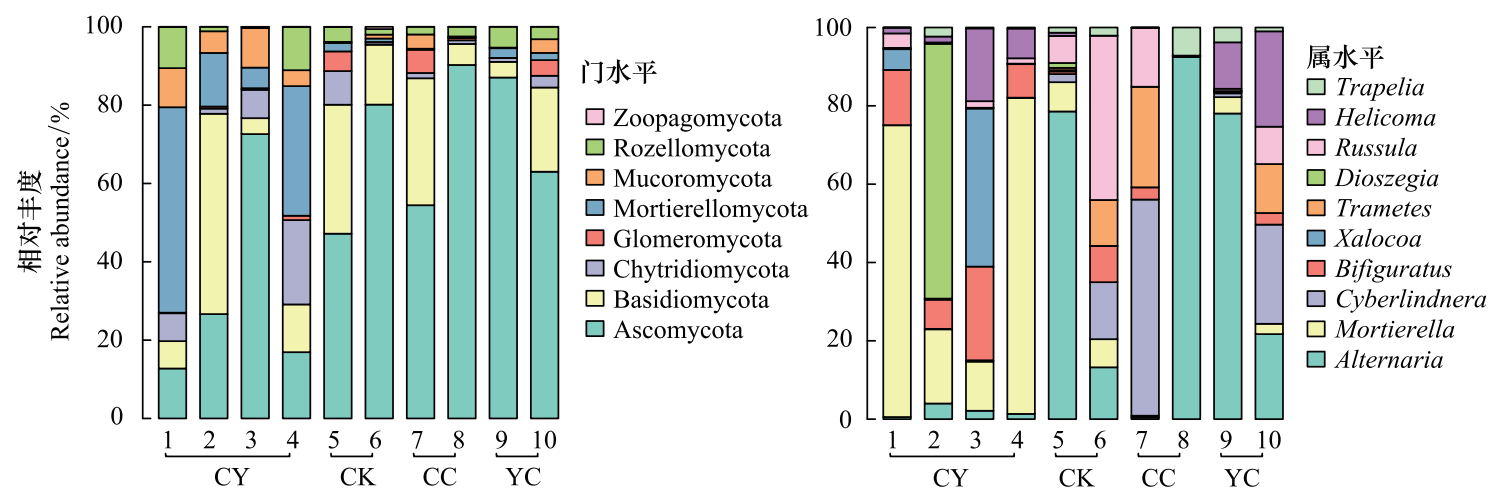

图 5 各样点水体真菌在门水平及属水平物种分布柱状堆积图

Fig.5 The relative percent contribution of aquatic fungal community at the phyla level and genus level for the different sites

Zoopagomycota: 捕虫需亚门; Rozellomycota: 罗兹菌门; Mucoromycota: 毛霉菌门; Mortierellomycota: 被狍霰门; Glomeromycota: 球囊菌门; Chytridiomycota: 壶菌门; Basidiomycota: 担子菌门; Ascomycota: 子囊菌门; Trapelia: 褐边衣属; Helicoma: 蜗狍属; Russula: 红菇属; Dioszegia: 未命名; Trametes: 栓菌属; Xalocoa: 未命名; Bifiguratus: 未命名; Cyberlindnera: 塞伯林德纳氏酵母属; Mortierella: 被狍霉属; Alternaria: 链格狍属
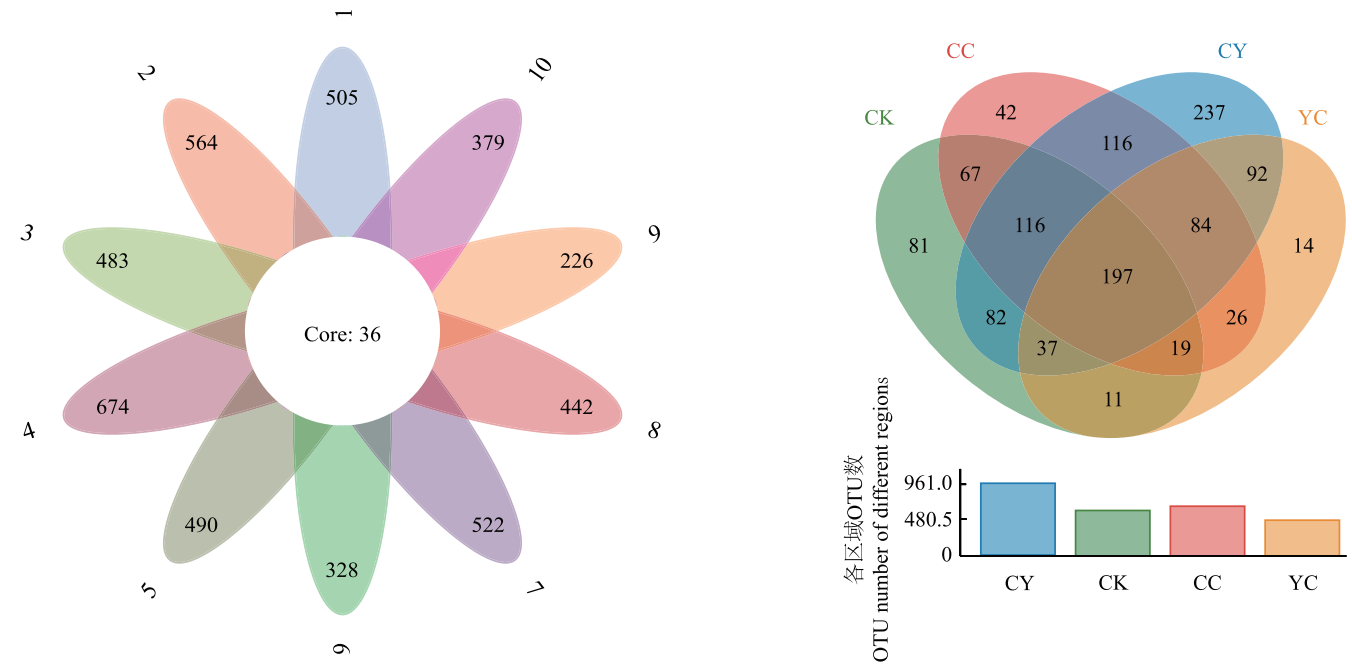

图 6 各样点及各区域水体真菌 OTU 水平 Venn 图

Fig.6 Venn diagram of aquatic fungal OTU levels in different sites and different regions

\section{4 羊卓雍错水体真菌多样性与水体理化因子的相关性分析}

如图 8 所示, 羊卓雍错水体浊度、 $\mathrm{COD} 、 \mathrm{NH}_{4}^{+}-\mathrm{N}$ 以及 $\mathrm{TN}$ 与水体真菌 Ace 指数以及 Chao 1 指数呈显著正相 关 $(P<0.05), \mathrm{NH}_{4}^{+}-\mathrm{N}$ 与 OTU 数呈显著正相关 $(P<0.05)$ 。相关性分析表明, 浊度、 $\mathrm{COD} 、 \mathrm{NH}_{4}^{+}-\mathrm{N}$ 以及 $\mathrm{TN}$ 是影 响羊卓雍错水体真菌丰富度的主要理化因子。

基于羊卓雍错水体真菌均一化 OTU 丰度矩阵, 进行去趋势对应分析 (DCA)。结果显示, 第一排序轴长度 为 2.4 , 故本研究选取冗余分析 (RDA)。通过向前选择篮选出 2 项理化指标进行 RDA 分析 (图 9),第 1 排序 轴对响应变量的解释度比例为 $22.4 \%$,第 2 排序轴为 $13.3 \%$, 二者总和达到 $35.7 \%$ 。环境因子间相关性在排序 图中有较直观的展现, EC、TDS、盐度以及 $\mathrm{pH}$ 间呈较强的正相关, $\mathrm{TP}$ 则与四者间呈负相关。浊度、 $\mathrm{NH}_{4}^{+}-\mathrm{N} 、 \mathrm{~T}$ 、 TN 以及 COD 之间呈较强的正相关。样点分布状况显示, 3 号与 1 号样点以及 6 号与 9 号样点的真菌群落结 构对 $\mathrm{TP}$ 和 $\mathrm{NH}_{4}^{+}-\mathrm{N}$ 有着相同的响应, 同一区域的样点在第一排序轴上分布接近, 而在第二排序轴上分布散乱, 

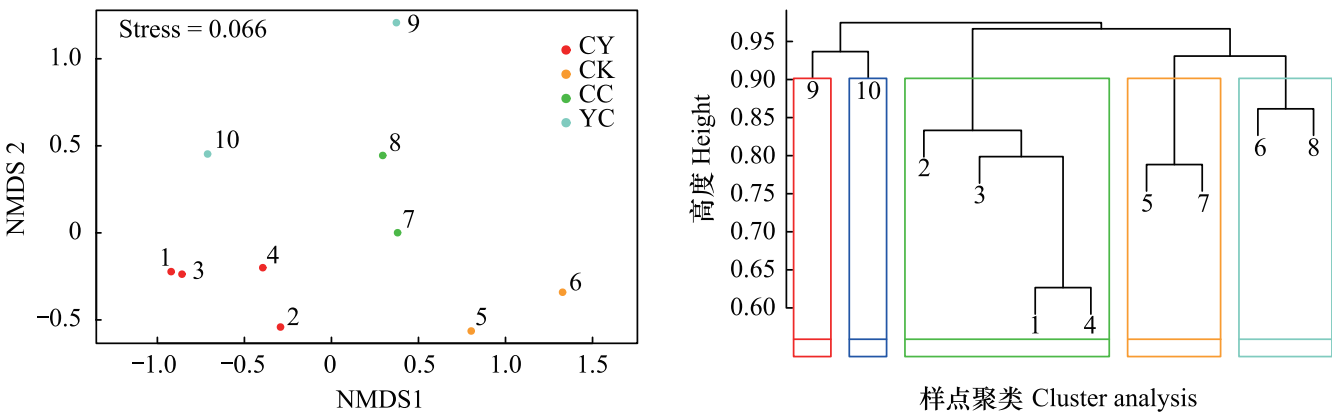

图 7 基于 Bray-Curtis 距离的非度量多维尺度 (NMDS) 分析和采样点聚类

Fig.7 Nonmetric multidimensional scaling (NMDS) and Cluster analysis plots using Bray-Curtis dissimilarity distance

\begin{tabular}{|c|c|c|c|c|c|c|c|c|c|c|c|}
\hline 0.10 & -0.26 & 0.62 & -0.32 & -0.31 & -0.33 & 0.48 & $0.67^{*}$ & 0.61 & 0.09 & OUT数 & 相关性系数 \\
\hline 0.17 & -0.42 & $0.72 *$ & -0.46 & -0.46 & -0.47 & $0.68^{*}$ & $0.74 *$ & $0.70^{*}$ & 0.27 & Ace & \\
\hline 0.20 & -0.44 & $0.75^{*}$ & -0.45 & -0.45 & -0.46 & $0.69^{*}$ & $0.76^{*}$ & $0.71^{*}$ & 0.28 & Chao 1 & \\
\hline-0.16 & -0.04 & 0.42 & -0.17 & -0.17 & -0.18 & 0.34 & 0.49 & 0.49 & -0.03 & Shannon & \\
\hline-0.47 & 0.21 & 0.23 & -0.09 & -0.09 & -0.10 & 0.38 & 0.21 & 0.43 & -0.04 & Simpson & \\
\hline
\end{tabular}

图 8 羊卓雍错水体真菌 $\alpha$-多样性指数及水体理化因子 Pearson 相关性系数

Fig.8 Pearson correlation coefficient between aquatic fungal $\alpha$-diversity indexes and environmental factors in Yamzhog Yumco Lake

* 表示在 $P<0.05$ 水平上显著; $* *$ 表示在 $P<0.01$ 水平上显著

这在一定程度上说明了同一区域不同样点水体真菌对 $\mathrm{TP}$ 有着相似的响应, 但对 $\mathrm{NH}_{4}^{+}-\mathrm{N}$ 的响应却不尽相同。 $\mathrm{TP}$ 和 $\mathrm{NH}_{4}^{+}-\mathrm{N}$ 对羊卓雍错水体真菌群落结构变化的贡 献率分别为 $22.4 \%$ 和 $13.3 \%, \mathrm{P}$ 值均小于 0.05 , 所以 $\mathrm{TP}$ 是影响羊卓雍错各样点水体真菌群落结构最显著的环 境因子, 其次为 $\mathrm{NH}_{4}^{+}-\mathrm{N}$ 。

\section{3 讨论}

真菌在水生生态系统中起着重要作用。文献显示, 真菌在其生命周期中大量利用周围难以被其他生物利 用的营养物质,并通过孢子及菌丝体进人水生生态系统 食物链, 其生命活动极大促进了水生生态系统物质循 环, 其群落结构及多样性也在一定程度上反映了湖泊水 体的质量状况 ${ }^{[35-36]}$ 。本研究的四个区域间虽有水体连 接,但地理位置、补水方式以及人为活动方式的不同使 得其水体理化性质存在较大差异。自 2005 年以来, 羊 卓雍错湖面蒸发加剧, 湖面剧烈萎缩, 湖水浓缩, 致使羊

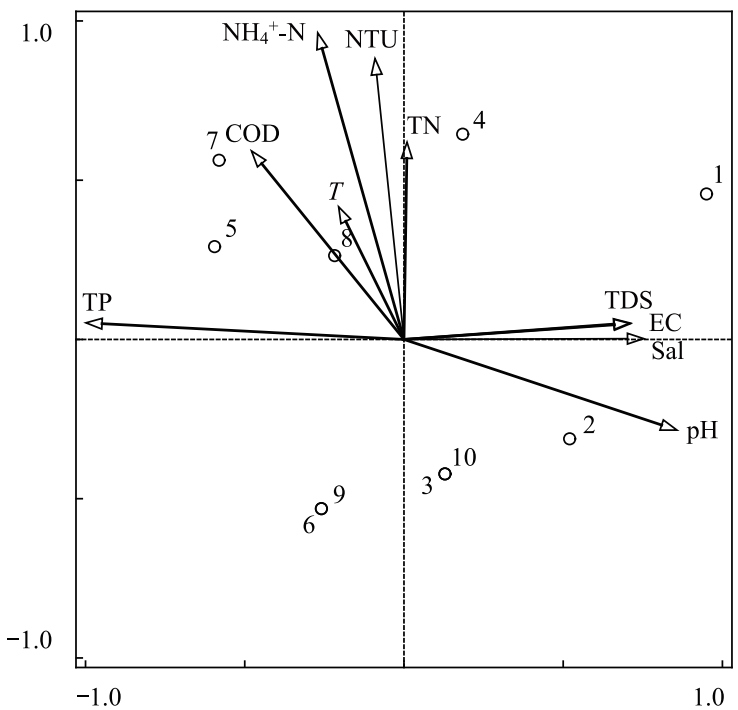

图 9 羊卓雍错水体真菌与理化因子 RDA 分析排序图

Fig.9 RDA ordination diagram of aquatic fungal associated with environmental factors in Yamzhog Yumco Lake 
卓雍错沿岸区及羊卓雍错湖心区 $\mathrm{pH} 、 \mathrm{EC} 、 \mathrm{TDS}$ 以及盐度均显著高于空母错沿岸区以及沉错沿岸区 ${ }^{[21]}$ 。由于 空母错主要由冰川融水补给, 水面高度较羊卓雍错和沉错高, 其湖水在丰水期补充羊卓雍错以及沉错 ${ }^{[21]}$, 水 体中溶解性物质随水流流出, 造成空母错沿岸区 EC、TDS 以及盐度显著低于其他 3 个区域。就 TP 而言, 羊卓 雍错沿岸区显著低于空母错沿岸区及沉错沿岸区,这可能是由于羊卓雍错沿岸区分布有全世界海拔最高的抽 水蓄能电站, 抽取雅鲁藏布江河水以及下放羊卓雍错湖水的运作机制一定程度上稀释了羊卓雍错沿岸区的 $\mathrm{TP}$ 含量。

参照《地表水环境质量标准》( GB 38382-2002) 基本项目标准限值, 羊卓雍错水体 $\mathrm{NH}_{4}^{+}-\mathrm{N}$ 、TN 以及 $\mathrm{TP}$ 浓 度均低于限值, 表明其水质为清洁, 但 COD 浓度却超出限值。考虑到沿岸区部分样点采样时水位偏低, 底泥 无法避免地被混人水样, 这可能是 COD 浓度超出限值的原因。因此, 本研究中理化因子数据无法真实地描述 羊卓雍错水体的清洁程度,但作为水体真菌群落结构及多样性的影响指标具有评价和分析意义。

本研究中 7 号、5 号以及 4 号样点水体真菌丰富度较高, 与 Chen 等 ${ }^{[11]}$ 在丹江口水库以及 Kong 等 ${ }^{[12]}$ 在鄱 阳湖的研究结果相似, 本研究发现, 羊卓雍错水体真菌群落丰富度与水体浊度、COD、 $\mathrm{NH}_{4}^{+}-\mathrm{N}$ 以及 $\mathrm{TN}$ 呈显著 正相关 $(P<0.05), 7$ 号、5 号以及 4 号样点水体较高的浊度、COD、 $\mathrm{NH}_{4}^{+}-\mathrm{N}$ 以及 $\mathrm{TN}$ 浓度是造成这种现象的主要 原因。Shannon 多样性指数以及 Simpson 多样性指数显示, 4 号与 7 号样点水体真菌多样性较高, 4 号与 7 号 样点分别位于空母错湖水输人羊卓雍错和沉错的河道口附近, 理化性质迥异的湖水输人所造成的区域小生境 的多样化是造成这种现象的可能原因。各区域间差异性分析显示, 羊卓雍错湖心区水生真菌 OTU 数量显著 低于羊卓雍错沿岸区 $(P<0.05)$ 。受湖水流动影响, 广阔湖区分布的植物残体等有机质会在湖岸区富集 ${ }^{[37]}$, 这为真菌生长繁殖提供了有利条件, 这可能是沿岸区水生真菌 OTU 数量较高的主要原因。其他 $\alpha$-多样性指 数在各区域间则不存在显著差异。

经 Unite 数据库比对后, 被注释的真菌门包括: 子囊菌门、被狍需门、担子菌门、壸菌门、毛霉菌门、罗兹菌 门、球囊菌门和捕虫霉亚门, 其中子囊菌门、被孢霉门以及担子菌门是羊卓雍错各样点水体真菌的主要门类, 子囊菌门以及担子菌门在各样点均有较多分布, 其也是水体中常见的 2 个真菌门类 ${ }^{[37]}$, 被狍霉门则主要分布 于羊卓雍错沿岸区 $\left(1-4\right.$ 号样点)。被孢霨门多被发现于土壤中, 是土壤真菌的常见门类 ${ }^{[38]}$ 。鉴于羊卓雍错 沿岸区为羊卓雍错主要旅游区域且 1 号及 4 号样点位于当地居民主要生产活动场所附近, 大量的人为活动增 加了土壤微生物群落与沿岸水体微生物群落交流的机会, 这可能是被狍霉门在羊卓雍错沿岸区水体中大量分 布的主要原因。就被注释的真菌属而言, 羊卓雍错沿岸区 4 个样点中, 1 号及 4 号样点主要以 Mortierella 为 主, 而 2 号及 3 号样点则分别以 Dioszegia 和 Xalocoa 为主, Mortierella 相对丰度较低, 这可能是由于羊卓雍错水 电站以及羊卓雍错观景台的设置一定程度上减少了土壤微生物群落与水体微生物群落的交流所造成的。 Dioszegia 为耐冷酵母, 在冰冻圈广泛分布 ${ }^{[39]}$, 但在本研究中仅在 2 号样点有大量分布, 在其他样点则很少出 现。2 号样点位于羊卓雍错蓄能电站, 推测 Dioszegia 是随雅鲁藏布江河水输人至羊卓雍错。相较于羊卓雍错 沿岸区的其他样点, 3 号样点Xalocoa、Bifiguratus 以及 Helicoma 相对丰度均较高, 这可能是由于 Mortierella 相 对丰度的降低为其他属微生物腾出生存空间所致。分析位于空母错的两个样点发现, 5 号及 6 号样点属水平 组成较为相似, 但 5 号样点 Alternaria 相对丰度为 $78.6 \%$, 占据绝对优势, 6 号样点水体真菌属水平分布则较为 均匀。这可能是由于 5 号样点除 TP 外的各项营养元素均显著高于 6 号样点所致。从位于沉错的两个样点可 以看出, 7 号及 8 号样点属水平组成差异较大, 其中 8 号样点 Alternaria 相对丰度可以达到 $92.5 \%$, 郑保海 等 ${ }^{[00]}$ 研究发现, Alternaria 丰度与水体温度呈极显著正相关, 推测 8 号样点较高的水体温度使得 Alternaria 大 量富集, 限制了其他属微生物的生长, 进而造成了这两个样点间水体真菌属水平的组成差异。9 号与 10 号样 点同属羊卓雍错湖心区, 其中 10 号样点位于雍布朵寺旁, 为信教群众采集圣水处, 靠近湖心小岛的地理位置 加之频繁的采集圣水活动是导致 10 号样点属水平真菌组成区别于 9 号样点而接近沿岸区各样点的可能原 因。就各样点真菌被注释情况而言, 5 号、6 号、9 号及 10 号样点在门水平和属水平存在大量未知类群。空母 错主要由冰川融水补给, 人湖河流对周边环境微生物资源存在富集作用, 这可能是 5 号及 6 号样点存在大量 
未知真菌类群的原因。相较于沿岸区, 湖心区营养物质含量及水体温度较低, 更加恶劣的生存环境是 9 号及 10 号样点真核微生物多为未知类群的可能原因。

各样点 OTU 水平 Venn 图显示, 10 个样点共有 OTU 数量仅为 36 , 羊卓雍错枝桠状湖岸以及各样点人为 活动方式及频率的差异是造成这种现象的可能原因。各区域 OTU 水平 Venn 图显示, 各区域间微生物群落组 成相似性较低, $\mathrm{RDA}$ 分析显示, 羊卓雍错各样点水体真菌群落结构显著受到 $\mathrm{TP}$ 以及 $\mathrm{NH}_{4}^{+}-\mathrm{N}$ 影响 $(P<0.05)$, 各区域间地理位置的差异以及水系发育程度不同导致的水体理化因子的差异可能是造成这种现象的主要 原因。

各区域间水体真菌群落结构差异明显, NMDS 分析结果可以将各区域明显区分开,但相较于分属于其他 区域的样点, 分属于羊卓雍错湖心区的 9 号及 10 号样点间水体真菌群落结构差异较大, 同样的结果在完全连 接聚合聚类分析中也有所体现,这进一步说明了地理位置及人为活动对水体真菌群落结构具有较大影响。由 于不同统计分析方法侧重不同,不同于 NMDS 分析所展现出的结果,完全连接聚合聚类分析显示, 5 号与 7 号 样点间水体真菌群落结构具有较大的相似性, 6 号与 8 号样点间水体真菌群落结构具有较大的相似性。观察 5 号与 7 号样点地理位置可知, 5 号与 7 号样点分别位于连接空母错与沉错的河道两端, 样点间水体真菌群落 更大的交流频率是造成这种现象的可能原因。在完全连接聚合聚类分析中, 羊卓雍错沿岸区的 4 个样点展现 出不同程度的相似性, 位于当地居民主要生产劳动场所附近的 1 号与 4 号样点水体真菌群落结构具有较高的 相似性, 位于羊卓雍错蓄能电站的 2 号样点与 1 号及 4 号样点间水生真菌群落结构则相似性较低。赵君 等 ${ }^{[41]}$ 研究发现, 土地利用方式对袁河流域浮游细菌群落结构有显著影响, 本研究结果一定程度上说明了人为 干扰方式的不同对羊卓雍错沿岸区水体真菌群落结构的影响也不尽相同。

\section{4 结论}

本研究探讨了羊卓雍错水体真菌群落结构及多样性, 分析了水体理化因子对其的影响。结果显示, 羊卓 雍错水体真菌资源丰富, 子囊菌门 (Ascomycota)、被孢霉门 (Mortierellomycota) 和担子菌门( Basidiomycota) 为 羊卓雍错水体真菌主要门类, 水体真菌丰富度主要受浊度、 $\mathrm{COD} 、 \mathrm{NH}_{4}^{+}-\mathrm{N}$ 以及 $\mathrm{TN}$ 影响, 水体真菌群落结构主 要受 $\mathrm{TP}$ 和 $\mathrm{NH}_{4}^{+}-\mathrm{N}$ 影响, 人为活动对羊卓雍错水体真菌群落结构也有较大影响。

\section{参考文献 (References) :}

[ 1 ] 杨桂山, 马荣华, 张路, 姜加虎, 姚书春, 张民, 曾海鳌. 中国湖泊现状及面临的重大问题与保护策略. 湖泊科学, 2010, 22(6): 799-810.

[ 2 ] 王苏民, 窦鸿身. 中国湖泊志. 北京: 科学出版社, 1998.

[ 3 ] 吴庆龙, 江和龙. 中国湖泊微生物组研究. 中国科学院院刊, 2017, 32(3): 273-279.

[ 4 ] Allison S D, Martiny J B H. Resistance, resilience, and redundancy in microbial communities. Proceedings of the National Academy of Sciences of the United States of America, 2008, 105(S1) : 11512-11519.

[ 5 ] 罗建桦, 陶华, 邢鹏, 吴庆龙. [微综述] 湖泊微生物宏基因组学研究进展. 湖泊科学, 2020, 32(1): 271-280.

[ 6 ] 董明华, 李治洷, 周斌, 周巧, 严亚萍, 晋方佑, 李云霄, 杨丽源, 李绍兰. 云南高原湖泊杞麓湖冬季可培养酵母菌多样性分析. 微生物 学报, 2016, 56(4): 603-613.

[ 7 ] 万晓君, 李一藏, 王曙光. 水华生消过程对巢湖沉积物微生物群落结构的影响. 环境科学, 2015, 36(1): 107-113.

[ 8 ] Cowan D A. Microbial genomes-the untapped resource. Trends in Biotechnology, 2000, 18(1) : 14-16.

[ 9 ] 孙欣, 高荣, 杨云锋. 环境微生物的宏基因组学研究新进展. 生物多样性, 2013, 21(4): 393-401.

[10］张雅洁, 李珂, 朱浩然, 张洪勋. 北海湖微生物群落结构随季节变化特征. 环境科学, 2017, 38(8): 3319-3329.

[11] Chen Z J, Yuan J, Sun F, Zhang F, Chen Y, Ding C Y, Shi J W, Li Y Y, Yao L G. Planktonic fungal community structures and their relationship to water quality in the Danjiangkou Reservoir, China. Scientific Reports, 2018, 8(1): 10596.

[12] Kong Z Y, Kou W B, Ma Y T, Yu H T, Ge G, Wu L. Seasonal dynamics of the bacterioplankton community in a large, shallow, highly dynamic Freshwater Lake. Canadian Journal of Microbiology, 2018, 64(11): 786-797.

[13] 黄小兰, 贾伟, 叶长盛, 简正军, 张建. 赣江下游河湖交错带微生物群落分布及其影响因素分析. 江西师范大学学报: 自然科学版, 
2019, 43(5): 501-507.

[14] 陈兆进, 丁传雨, 朱静亚, 李冰, 黄进, 杜宗明, 王亚, 李玉英. 丹江口水库枯水期浮游细菌群落组成及影响因素研究. 中国环境科学, 2017, 37(1): 336-344.

[15] 罗芳, 鲁伦慧, 李哲, 付川, 目涁. 基于宏基因组学的三峡库区重庆主城段水体浮游微生物群落的组成和功能分析. 三峡生态环境监测, 2019, 4(3): 1- 10 .

[16] 刘晋仙, 李峩, 罗正明, 王雪, 暴家兵, 柴宝峰. 亚高山湖群中真菌群落的分布格局和多样性维持机制. 环境科学, 2019，40(5)： 2382-2393.

[17] Callieri C, Hernández-Avilés S, Salcher M M, Fontaneto D, Bertoni R. Distribution patterns and environmental correlates of Thaumarchaeota abundance in six deep subalpine lakes. Aquatic Sciences, 2016, 78(2): 215-225.

[18] Immerzeel W W, Van Beek L P H, Bierkens M F P. Climate change will affect the Asian water towers. Science, 2010, 328(5984): 1382-1385.

[19］郭春燕, 岳琳艳, 赵康, 邢鹏, 孔维栋. 水样保存方法对青藏高原湖泊可培养微生物的影响. 生态学杂志, 2018, 37(8): 2541-2548.

[20］王荻. 青藏高原南部羊卓雍错流域降水稳定同位素与大尺度大气环流关系研究 [D ]. 昆明: 云南大学, 2018.

[21］孙瑞, 张雪芹, 郑度. 藏南羊卓雍错流域水化学区域差异及其成因. 地理学报, 2013, 68(1): 36-44.

[22] 间瑞强, 沈渭寿, 赵卫, 欧阳琰. 雅鲁藏布江中游河谷黑颈鹤生境适宜性及其保护状况动态变化. 生态与农村环境学报, 2018, 34(2)： 146- 152 .

[23］宋立东. 雅鲁藏布江中游河谷黑颈鹤保护区生态环境质量评价研究 [D ]. 北京: 中国地质大学(北京), 2019.

[24] 张国钢, 刘冬平, 钱法文, 侯韵秋, 陈丽霞, 戴强, 陆军. 西藏南部羊卓雍错水鸟群落及斑头雁活动区域特征. 生态学报, 2016, 36(4)： 946- 952 .

[25] 刘冬平, 张国钢, 钱法文, 侯韵秋, 戴铭, 江红星, 陆军, 肖文发. 西藏雅鲁藏布江中游斑头雁的越冬种群数量、分布和活动区. 生态学 报, 2010, 30(15): 4173-4179.

[26] 王传旗, 张文静, 德吉卓玛, 邓时梅, 梁莎, 苗彦军. 西藏浪卡子县野生垂穗披碱草种子萌发对水盐胁迫的响应. 种子, 2018，37(7)： $39-43$.

[27］郑有坤. 青藏高原土壤放线菌的多样性及其对三七根腐病的生防潜力 [D ]. 昆明: 云南大学, 2015.

[28] 时玉, 孙怀博, 刘勇勤, 侯居峙, 朱立平, 褚海燕. 青藏高原淡水湖普莫雍错和盐水湖阿翁错湖底沉积物中细菌群落的垂直分布. 微生物 学通报, 2014, 41(11): 2379-2387.

[29] 除多, 旺堆, 普穷, 德吉央宗, 拉巴卓玛, 普布次仁, 张雪芹, 孙瑞. 西藏羊卓雍错湖面遥感监测模型及近期变化. 冰川冻土, 2012, 34 (3) : 530-537.

[30］刘天仇. 西藏羊卓雍错水位动态研究. 地理科学, 1995, 15(1) : 55-62, 100-100.

[31] 除多, 普穷, 拉巴卓玛, 朱立平, 张雪芹, 普布次仁, 德吉央宗, 孙瑞. 近 40a 西藏羊卓雍错湖泊面积变化遥感分析. 湖泊科学, 2012, 24 (3) : 494-502.

[32] 边多, 杜军, 胡军, 李春, 李林. 1975-2006 年西藏羊卓雍错流域内湖泊水位变化对气候变化的响应. 冰川冻土, 2009, 31(3) : 404-409.

[33] 孙立夫, 张艳华, 裴克全. 一种高效提取真菌总 DNA 的方法. 菌物学报, 2009, 28(2): 299-302.

[34] 商潘路, 陈胜男, 黄廷林, 张海涵, 康鹏亮, 王跃, 㻇珍芳, 刘形永. 深水型水库热分层诱导水质及真菌种群结构垂向演替. 环境科学, 2018, 39(3): 1141-1150.

[35] Wong M K M, Goh T K, Hodgkiss I J, Hyde K D, Ranghoo V M, Tsui C K M, Ho W H, Wong W S W, Yuen T K. Role of fungi in freshwater ecosystems. Biodiversity and Conservation, 1998, 7(9): 1187-1206.

[36] Azam F, Fenchel T, Field J G, Gray J S, Meyer-Reil L A, Thingstad F. The ecological role of water-column microbes in the sea. Marine Ecology Progress Series, 1983, 10(3): 257-263.

[37] 宣淮翔, 安树青, 孙庆业, 周长芳. 太湖不同湖区水生真菌多样性. 湖泊科学, 2011, 23(3): 469-478.

[38] 耿德洲, 黄菁华, 霍娜, 王楠, 杨盼盼, 赵世伟. 黄土高原半干旱区不同种植年限紫花苜葆人工草地土壤微生物和线虫群落特征. 应用生 态学报, 2020,31(4) : 1365-1377.

[39] 李师翁, 陈拓, 张威, 刘光琇. 冰冻圈微生物学: 回顾与展望. 冰川冻土, 2019, 41(5): 1221-1234.

[40］郑保海, 王晓宇, 李英军, 陈彦, 李百炼, 李玉英, 陈兆进. 丹江口库区浮游真菌组成与功能及其影响因素. 环境科学, 2021, 42(1)： 234-241.

[41] 赵君, 王鹏, 徐启渝, 张华, 丁明军. 袁河流域不同土地利用方式下河流浮游细菌群落结构特征. 环境科学学报, 2020, 40(3) : 890-900. 